\title{
Beban Pencemar Dan Kapasitas Asimilasi Amonium dan Nitrat Saat Pucak Musim Barat di Teluk Jakarta
}

\author{
Yulianto Suteja* \\ Program Studi Ilmu Kelautan, Fakultas Kelautan dan Perikanan, Universitas Udayana, Bukit Jimbaran, Bali 80361, Indonesia \\ * Penulis koresponden. Tel.: +62-81-803-6497-90 \\ Alamate-mail: yuliantosuteja@gmail.com
}

Diterima (received) 21 Februaari 2016; disetujui (accepted) 24 Mei 2016; tersedia secara online (available online) 28 Mei 2016

\begin{abstract}
Jakarta Bay is a bay that has an important role in Jakarta, but the activity in this area lead to the potential for pollution mainly ammonium and nitrate. Pollution peaks generally occur during the rainy season (west monsoon). Pollution that enters the bay can be neutralized naturally by water as long as the amount does not exceed the asimilation capacity. This study aims to calculate the total input (load), assimilation capacity, and residence time of ammonium and nitrate in Jakarta Bay in the rainy season. Data from this study is derived from secondary data. For the total input of pollutants are calculated from the input stream, the atmosphere and the boundary. From the research found that the Jakarta Bay had a total load of pollutants $\mathrm{NH}_{4}$ at $115.8 \times 10^{9} \mathrm{mmol} \mathrm{N} / \mathrm{month}$ and NO 346.5 x $10^{9} \mathrm{mmol} \mathrm{N} /$ month. The biggest contributor to the pollution comes from the boundary $\mathrm{NH}_{4}$ is $56.9 \%$ and $\mathrm{NO}_{3}$ from the river $70.1 \%$. Load from Citarum river for NH4 around $3.8 \times 10^{10} \mathrm{mmol} \mathrm{N} /$ month and $\mathrm{NO}_{3}$ around $3.0 \times 10^{10} \mathrm{mmol} \mathrm{N} / \mathrm{month}$ higher than Marunda, Priok and Angke the rivers. Assimilation capacity of Jakarta bay for NH4 around $25.7 \times 10^{9} \mathrm{mmol} \mathrm{N} / \mathrm{month}$ and NO3 of $24.1 \times 10^{9}$ $\mathrm{mmol} \mathrm{N} /$ month. It shows the total load of pollutants entering the Jakarta Bay is greater than the assimilation capacity. The residence time of water in the Bay of Jakarta is 13.3 days longer than the residence time of $\mathrm{NH}_{4}$ and $\mathrm{NO}_{3}$ which were only 8.6 and 9.2 days.
\end{abstract}

Keywords: Load; assimilation capacity; Jakarta Bay

\begin{abstract}
Abstrak
Teluk Jakarta merupakan teluk yang memiliki peranan penting bagi kehiduan di Jakarta, namun tinginya aktifitas di teluk ini menyebabkan potensi untuk terjadinya pencemaran sangat tingi terutama dari amonium dan nitrat. Puncak pencemaran umunya terjadi terutama saat musim hujan (musim barat). Pencemaran yang masuk ke dalam teluk dapat dinetralisir secara alami oleh perairan asalkan jumlah pencemaran tidak melebihi kapasitas asimilasnya. Penelitian ini bertujuan untuk melakukan penghitungan total masukan (load), kapasitas asimilasi dan waktu tinggal amonium dan nitrat di Teluk Jakarta pada musim hujan. Data dari penelitian ini berasal dari data sekunder. Untuk total masukan bahan pencemar dihitung dari input sungai, atmosfer dan bidang batas. Dari penelitian didapatkan bahwa Teluk Jakarta memiliki total load bahan pencemar $\mathrm{NH}_{4}$ sebesar 115,8 x $10^{9} \mathrm{mmol} \mathrm{N} / \mathrm{bulan}$ dan $\mathrm{NO}_{3}$ sebesar $46,5 \times 10^{9} \mathrm{mmol}$ $\mathrm{N} /$ bulan. Penyumbang terbesar untuk pencemaran $\mathrm{NH}_{4}$ berasal dari bidang batas sebesar 56,9\% sedangkan untuk $\mathrm{NO}_{3}$ berasal dari sungai sebesar 70,1\%. Sungai citarum memberikan beben pencemar $\mathrm{NH}_{4}$ sebesar 3,8 x $10^{10} \mathrm{mmol} \mathrm{N} /$ bulan dan $\mathrm{NO}_{3}$ sebesar $3,0 \times 10^{10}$ mmol N/bulan yang paling tinggi dibandingkan Sungai Marunda, Priok dan Angke. Kapasitas asimilasi teluk Jakarta untuk $\mathrm{NH}_{4}$ sebesar $25,7 \times 10^{9} \mathrm{mmol} \mathrm{N} /$ bulan dan $\mathrm{NO}_{3}$ sebesar $24,1 \times 10^{9} \mathrm{mmol} \mathrm{N} /$ bulan. Hal ini menunjukkan total load bahan pencemar yang memasuki Teluk Jakarta lebih besar dari kapasitas asimilasi teluk. Waktu tinggal air di dalam teluk Jakarta selama 13,3 hari lebih besar dibandingkan waktu tinggal $\mathrm{NH}_{4}$ dan $\mathrm{NO}_{3}$ yang hanya 8,6 dan 9,2 hari.
\end{abstract}

Kata Kunci: beban pencemar; kapsiatas asimilasi; Teluk Jakarta

\section{Pendahuluan}

Teluk Jakarta merupakan satu-satunya teluk yang terdapat di Provinsi Daerah Khusus Ibukota (DKI) Jakarta. Teluk Jakarta memiliki peran yang sangat penting, diantaranya menunjang kehidupan, pemasok sumberdaya alam, tempat rekreasi dan meregulasi limbah. Di daerah pesisir Teluk Jakarta juga berkembang sekitar 50 industri yang bergerak diberbagai bidang seperti transpotasi, galangan kapal, dan pariwisata (Arifin, 2004). Menurut Kusma (2015) berbagai kegiatan didarat akan sangat mempengaruhi kualitas perairan teluk jakarta sehingga teluk jakarta tidak bisa menjalankan fungsinya secara optimal. Berbagai pencemaran yang ada didarat akan masuk ke perairan laut terutama melalui sungai (Sanusi dan Putranto, 2009). Teluk Jakarta merupakan daerah tempat bermuara 13 sungai yang membawa bahan limbah dari daerah JakartaBogor-Bekasi-Depok-Tangerang-Bekasi (JABODETABEK) (Rositasari, 2011). Ditambahkan oleh Ahmad (2012) bahwa $83 \%$ dari 13 sungai yang bermuara ke Teluk Jakarta telah masuk dalam kategori tercemar berat. Sungai-sungai tersebut membawa berbagai macam jenis limbah yang bersifat toksik ke perairan Teluk Jakarta.

Pencemaran pada Teluk Jakarta tidak hanya berasal dari aliran sungai yang bermuara, namun juga berasal dari atmosfer dan perairan sekelilingnya. Pencemaran dari atmosfer merupakan imbas dari polusi udara yang terjadi di daratan sekelilingnya dan bereaksi dengan alam 
sehingga turun bersama air hujan. Menurut Sanusi dan Putranto (2009) semakin tinggi polusi udara yang terjadi di darat maka kemungkinan masukan pencemar dari atmosfer juga tinggi. Namun demikian, hal tersebut tidak lepas dari pola pergerakan angin yang membawanya sebagai fenomena alam. Teluk Jakarta yang merupakan perairan terbuka tidak lepas dari pengaruh sekeliling/bidang batas (boundery), termasuk di dalamnya pergerakan arus dan musim. Wyrtki (1961) mengemukakan Indonesia memiliki 2 musim yang dipengaruhi oleh pola pergerakan angin yang berbeda, yaitu musim hujan yang dipengaruhi oleh angin muson barat dan musim kemarau yang dipengaruhi oleh angin muson timur. Kedua pola angin tersebut mengakibatkan terjadinya perbedaan tingkat masukkan pencemar di Teluk Jakarta yang juga akan berdampak kepada kondisi organisme yang hidup di dalamnya. Pada saat musim barat, intensitas hujan akan meningkat (Aldrian and Susanto, 2003; As-syakur, 2015), sehingga masukan bahan bahan pencemar dari atmosfer dan daratan akan semakin tinggi (Chester, 1990). Nugrahadi et al. (2010) menyatakan bahwa masukan nurien ke Teluk Jakarta sangat tinggi pada saat musim hujan (musim barat).

Pencemaran di Teluk Jakarta dapat berupa limbah organik (Alfiansah et al., 2014) dan inorganik (Nugrahadi et al., 2010; Putri et al., 2012). Limbah inorganik ini dapat berupa Amonium $\left(\mathrm{NH}_{4}\right)$ dan Nitrat $\left(\mathrm{NO}_{3}\right)$ yang banyak dihasilkan dari aktifitas industri dan rumah tangga (Nugrahadi et al., 2010). Pada kondisi normal, suatu sistem perairan memiliki kemampuan untuk mengeluarkan bahan pencemar dan memulihkan kondisi sistem menjadi stabil dan aman untuk lingkungan maupun organisme di dalamnya. Namun hal tersebut akan menjadi berbeda bila masukan pencemar telah melebihi kemampuan sistem untuk mengeluarkan dan memulihkan diri. Oleh karena itu, penelitian ini bertujuan untuk melakukan penghitungan total masukan (load), kapasitas asimilasi dan waktu tingal $\mathrm{NH}_{4}$ dan $\mathrm{NO}_{3}$ di Teluk Jakarta pada musim barat yang menjadi puncak dari masukan bahan pencemar ke perairan.

\section{Metode Penelitian}

\subsection{Waktu dan lokasi}

Data yang digunakan adalah data kondisi nutrien Teluk Jakarta pada puncak musim barat yaitu bulan Desember 2000. Teluk Jakarta secara geografis terletak pada garis bujur $106^{\circ} 33^{\prime} \mathrm{BT}-107^{\circ} 30^{\prime} \mathrm{BT}$ dan garis lintang $5^{\circ} 48^{\prime}$ 30" LS - 6 10 ' 30" LS. Teluk Jakarta dibatasi oleh Tanjung Kait di bagian barat, Tanjung Karawang di bagian timur, bagian luar Kepulauan Seribu dibagian utara dan pesisir Jakarta dibagian selatan. Teluk Jakarta memiliki luas $\pm 490 \mathrm{~km}^{2}$, panjang pantai hingga $40 \mathrm{~km}$ dan rata-rata kedalaman $15 \mathrm{~m}$ (Koropitan et al., 2009). Peta lokasi studi dapat dilihat pada Gambar 1. Load sungai yang dihitung di teluk jakarta hanya berasal dari Sungai Angke (mewakili load darat dari bagian barat teluk), Priok dan Marunda (mewakaili load dari bagian tengah teluk) dan Citarum (mewakili load dari bagian timur teluk).

\subsection{Analisis data}

Data yang dianalisis merupakan data sekunder dari Koropitan et al. (2009). Data-data tersebut kemudian dianalisis sehingga diperoleh nilai Beban Pencemar (load) $\mathrm{NH}_{4}$ dan $\mathrm{NO}_{3}$ dari sungai, curah hujan, dan bidang batas, serta kapasitas asimilasi dan waktu tinggal (residence time) nutrien di Teluk Jakarta.

\subsubsection{Beban pencemar (load)}

Load merupakan jumlah suatu unsur pencemar yang terkandung dalam air (KepMenLH no 110 Tahun 2003). Beban pencemar suatu perairan dapat berasal dari masukan sungai, air hujan, dan bidang batas. Load yang dari input sungai dan air hujan diperoleh dengan menggunakan persamaan (EPA, 2009):

$$
\begin{aligned}
& W=Q . C \\
& W_{\mathrm{atm}}=J_{\mathrm{atm}} \cdot A_{3}
\end{aligned}
$$

dimana

$W$ : load dari sungai (mmol $N /$ bulan)

$Q \quad$ : debit sungai, hujan, dan bidang batas $\left(\mathrm{m}^{3} / \mathrm{s}\right)$

$C$ : konsentrasi nutrien dalam air sungai, hujan dan bidang batas ( $\mathrm{mmol} \mathrm{N} / \mathrm{m}^{3}$ )

$W_{\text {atm }}$ : load dari atmosfer (hujan) (mmol $N /$ bulan)

$\mathrm{Jatm}_{\mathrm{atm}}$ : fluks air hujan ( $\mathrm{mmol} / \mathrm{m}^{2}$.bulon)

$A_{1} \quad$ : luas permukaan Teluk Jakarta $\left(\mathrm{m}^{2}\right)$

Fluks yang berasal dari air hujan $\left(J_{\text {arm }}\right)$ diperoleh dari persamaan (Chester, 1990) :

$$
l_{\mathrm{atm}}=\overline{\mathrm{u}} \cdot \boldsymbol{C}
$$

dengan $\bar{u}$ : curah hujan ( $\mathrm{mm} /$ bulan)

Load yang diperoleh dari bidang batas, dibedakan menjadi bidang batas input yang menambah load nutrien dalam Teluk Jakarta, dan bidang batas output yang mengurangi load nutrien dalam teluk. Angin muson barat yang bergerak dari barat ke timur, mengakibatkan arus dalam teluk bergerak dari barat ke timur, sehingga arus barat menjadi batas input dan arus timur menjadi batas output (Gambar 2).

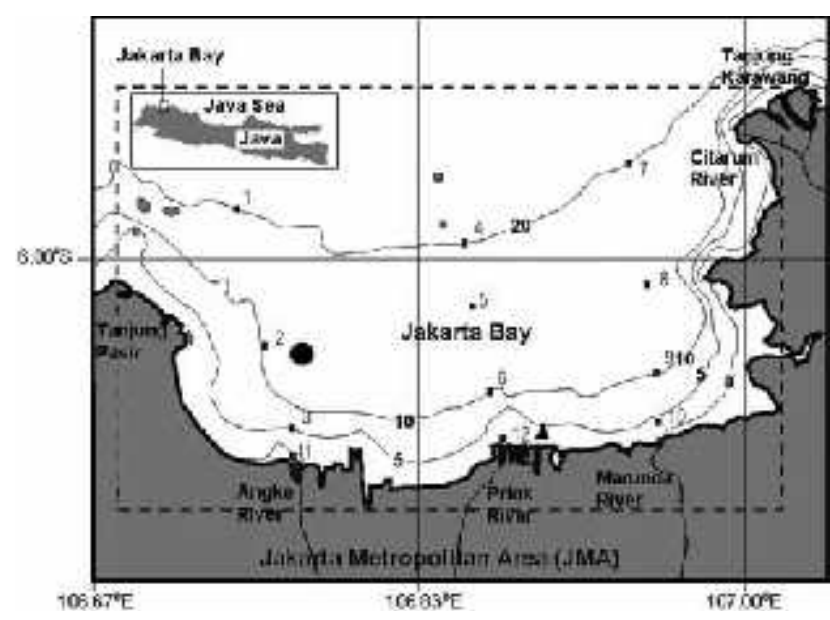

Gambar 1. Peta Lokasi (Koropitan et al. (2009) 
Tabel 1.

Kadungan $\mathrm{NH}_{4}$ dan $\mathrm{NO}_{3}$ dari sungai dan curah hujan, debit aliran sungai, dan curah hujan

\begin{tabular}{ll}
\hline Parameter & Konsentrasi \\
\hline Debit Sungai Angke $\left(\mathrm{m}^{3} / \mathrm{s}\right)$ & 38 \\
Debit Sungai Priok $\left(\mathrm{m}^{3} / \mathrm{s}\right)$ & 21,3 \\
Debit Sungai Marunda $\left(\mathrm{m}^{3} / \mathrm{s}\right)$ & 17,6 \\
Debit Sungai Citarum $\left(\mathrm{m}^{3} / \mathrm{s}\right)$ & 418,58 \\
Air Hujan $(\mathrm{mm})$ & 225 \\
Konsentrasi $\mathrm{NH}_{4}$ di Sungai Angke $\left(\mathrm{mmol} \mathrm{N} \mathrm{m}^{-3}\right)$ & 38,8 \\
Konsentrasi $\mathrm{NH}_{4}$ di Sungai Priok $\left(\mathrm{mmol} \mathrm{N} \mathrm{m}^{-3}\right)$ & 64,5 \\
Konsentrasi $\mathrm{NH}_{4}$ di Sungai Marunda $\left(\mathrm{mmol} \mathrm{N} \mathrm{m}^{-3}\right)$ & 11,7 \\
Konsentrasi $\mathrm{NH}_{4}$ di Sungai Citarum $\left(\mathrm{mmol} \mathrm{N} \mathrm{m}^{-3}\right)$ & 34,9 \\
Konsentrasi $\mathrm{NO}_{3}$ di Sungai Angke $\left(\mathrm{mmol} \mathrm{N} \mathrm{m}^{-3}\right)$ & 7,5 \\
Konsentrasi $\mathrm{NO}_{3}$ di Sungai Priok $\left(\mathrm{mmol} \mathrm{N} \mathrm{m}^{-3}\right)$ & 35,2 \\
Konsentrasi $\mathrm{NO}_{3}$ di Sungai Marunda $\left(\mathrm{mmol} \mathrm{N} \mathrm{m}^{-3}\right)$ & 6,4 \\
Konsentrasi $\mathrm{NO}_{3}$ di Sungai Citarum $\left(\mathrm{mmol} \mathrm{N} \mathrm{m}^{-3}\right)$ & 27,3 \\
Konsentrasi $\mathrm{NH}_{4}$ di air hujan $\left(\mathrm{mmol} \mathrm{N} \mathrm{m} \mathrm{mm}^{-3}\right)$ & 37,2 \\
Konsentrasi $\mathrm{NO}_{3}$ di air hujan $(\mathrm{mmol} \mathrm{N} \mathrm{m})$ & 23,5 \\
\hline
\end{tabular}

(Sumber : Koropitan et al. 2009)

Load bidang batas ini diperoleh dengan menggunakan persamaan (1), dimana flow $Q$ diperoleh dengan menggunakan persamaan (EPA, 2009):

$$
Q=A \cdot \bar{V}
$$

dimana :

$$
\begin{aligned}
& \text { A : luas bidang batas }\left(\mathrm{m}^{2}\right) ; \\
& \bar{\nabla} \quad \text { : kecepatan arus bidang batas }(\mathrm{m} / \mathrm{s})
\end{aligned}
$$
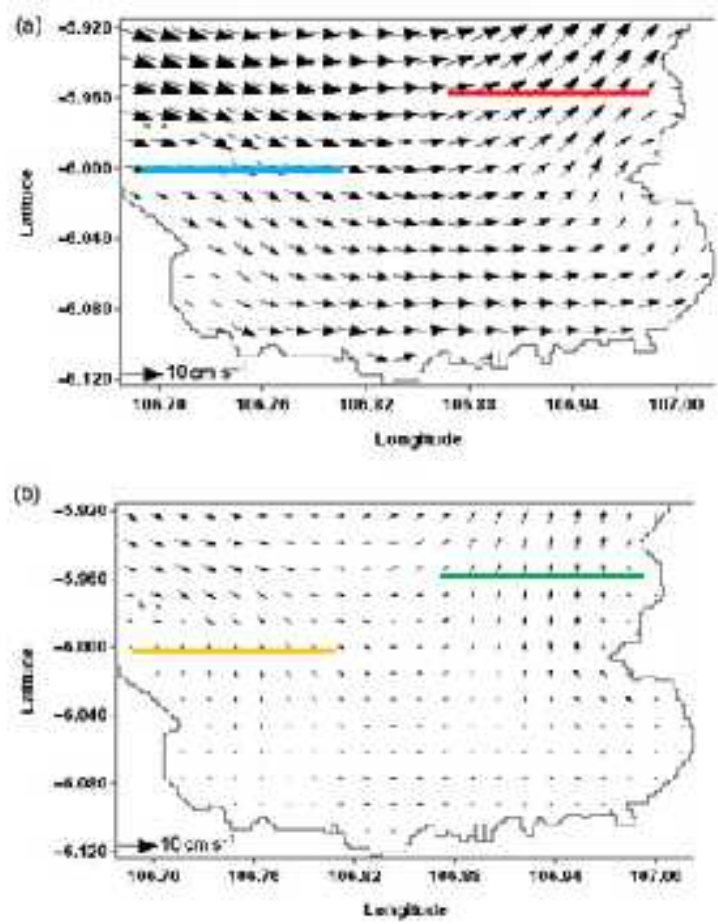

Gambar 2. Arus residu bagian permukaan (a) dan dasar (b) musim barat bidang batas input (garis biru dan kuning) dan output (garis merah dan hijau) (modifikasi dari Koropitan et al., 2009)

Luas bidang batas diperoleh dari selisih longitude sebagai panjang, dan kedalaman sebagai lebar (Gambar 3). Data kedalaman diperoleh dari nilai kedalaman yang terdapat pada peta batimetri (Gambar 1).

Pada bidang input :
Kedalaman $=(20+10) / 2=15 \mathrm{~m}$

Selisih longitude

$=100,88^{\circ}-107,00^{\circ}=0,12^{\circ}$ dengan $1^{\nu}=110 \mathrm{~km}$, maka $=0,12^{\circ} \times 110 \mathrm{~km}=13,2 \mathrm{~km}=1,32.10^{4} \mathrm{~m}$

Luas bidang input

$=1,32.10^{4} \mathrm{~m}$ × $15 \mathrm{~m}=1,98.10^{3} \mathrm{~m}^{2}$

Pada bidang output :

Kedalaman $=(20+10+5) / 3=11,0 / \mathrm{m}$

Selisih longitude

$=100,70^{\circ}-100,82^{\nu}=0,12^{\nu}$ dengan

$1^{\prime \prime}=110 \mathrm{~km}$, maka

$=0,12^{\circ} \times 110 \mathrm{~km}=13,2 \mathrm{~km}=1,32 \cdot 10^{4} \mathrm{~m}$

Luas bidang input

$1,32 \cdot 10^{4}$ m $x 11,6 / m=1,54 \cdot 10^{\circ} \mathrm{m}^{2}$

Rata-rata kecepatan arus bidang batas diperoleh dari Koropitan et al., 2009 (Tabel 2).

\begin{tabular}{|c|c|}
\hline Barat Teluk Jakarta (Output) & Timur Teluk Jakarta (Input) \\
\hline Permukaan & Permukaan \\
\hline$\quad y_{0}, 10^{4} \mathrm{~m} / \mathrm{s}$ & $1,812 \mathrm{~b} .10^{\circ} \mathrm{m} / \mathrm{s}$ \\
\hline Dasar & Dasar \\
\hline $1,52.10^{*} \mathrm{~m} / \mathrm{s}$ & $2,812 b .10^{*} \mathrm{~m} / \mathrm{s}$ \\
\hline Rata-rata: $b, b 1.10^{\circ} \mathrm{m} / \mathrm{s}$ & Rata-rata: $b, 312 b, 10^{*} \mathrm{~m} / \mathrm{s}$ \\
\hline
\end{tabular}

Tabel 2.

Rata-rata kecepatan arus di bidang batas

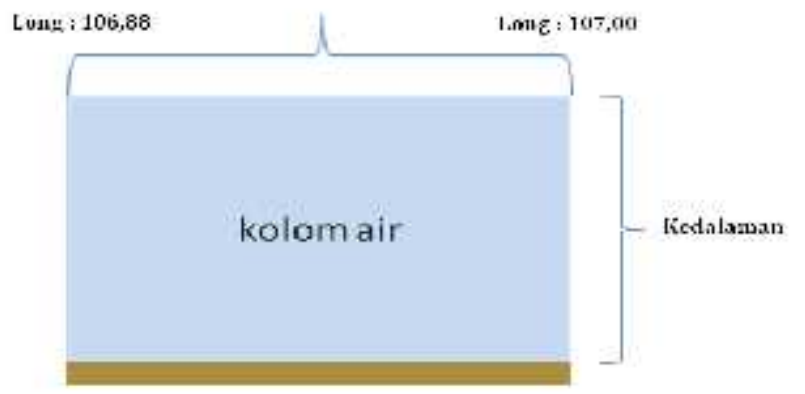

Gambar 3. Ilustrasi penghitungan luas bidang batas

\subsubsection{Beban pencemar (load)}

Kapasitas asimilasi atau daya tampung beban pencemar merupakan kemampuan air pada suatu sumber air, untuk menerima masukan beban pencemar tanpa mengakibatkan air tersebut menjadi cemar (KepMenLH no 110 Tahun 2003). Kapasitas asimilasi dapat diperoleh dengan persamaan berikut (EPA, 2009):

$$
u=\frac{W}{C}
$$

Dimana :

w : merupakan total load yang memasuki badan air (mmol/buian)

$C$ : rata-rata konsentrasi nutrien di badan air $\left(\mathrm{mmol} N / \mathrm{m}^{\mathrm{a}}\right)$ 
Konsentrasi nutrien diperoleh dengan mencari rata-rata konsentrasi $\mathrm{NH}_{4}$ dan $\mathrm{NO}_{3}$ yang terdapat di Teluk Jakarta (Gambar 4).

(a)

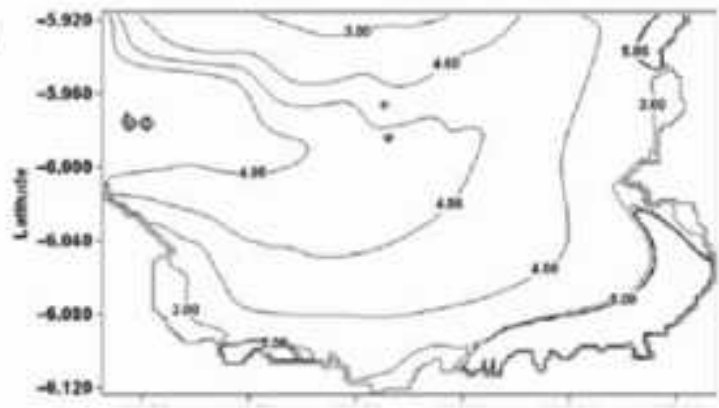

(b)

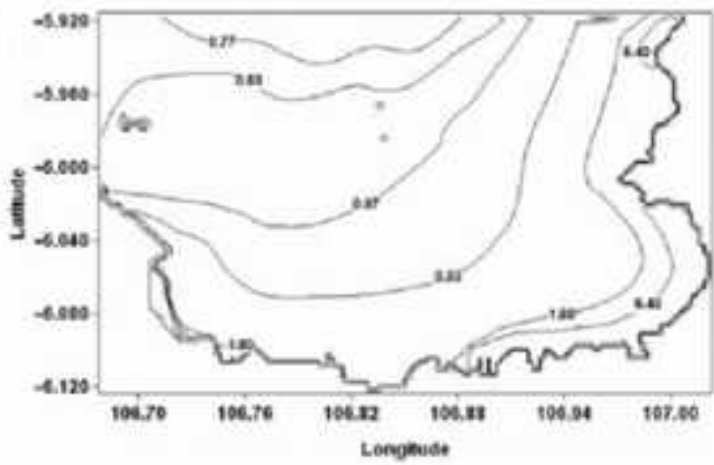

Gambar 4. Peta konsentrasi $\mathrm{NH}_{4}$ (a) dan $\mathrm{NO}_{3}$ (b) Teluk Jakarta (Koropitan et al., 2009)

\subsubsection{Beban pencemar (load)}

Residence time merupakan rata-rata waktu untuk elemen agar tetap berada di laut sebelum keluar dari badan air, maupun mengendap ke sedimen (Libes, 1992). Residence time diperoleh dengan persamaan (Chester, 1990):

$$
\begin{aligned}
& { }_{{ }^{{ }_{w}}}=\frac{V}{U} \\
& { }_{{ }_{c}}=\frac{V}{u}
\end{aligned}
$$

\section{Dimana}

${ }^{{ }_{W}}$ : residence time massa air (har $\left.i\right)$

$V \quad$ : volume badan air $\left(\mathrm{m}^{\mathrm{a}}\right)$

$Q \quad$ : total debit massa air sungai, hujan dan bidang batas $\left(\mathrm{m}^{3} / \mathrm{s}\right)$

${ }^{2} \mathrm{C}$ : residence time nutrien (har $i$ )

u : kapasitas asimilasi (mmol/bulan)

\section{Hasil dan Pembahasan}

\subsection{Load (Beban Pencemar)}

Total pencemaran nutrien berupa $\mathrm{NH}_{4}$ dan $\mathrm{NO}_{3}$ pada Teluk Jakarta berturut-turut $1,2 \times 10^{11} \mathrm{mmol} \mathrm{N} / \mathrm{bulan}$ dan $4,7 \times 10^{10} \mathrm{mmol} \mathrm{N} / \mathrm{bulan}$. Total load nutrien tersebut berasal dari masukan air sungai, terbawa bersama air hujan (atmosfer), dan dari bidang batas (Gambar 5). Secara keseluruhan, $\mathrm{NH}_{4}$ paling besar berasal dari bidang batas dan $\mathrm{NO}_{3}$ dominan berasal dari sungai.

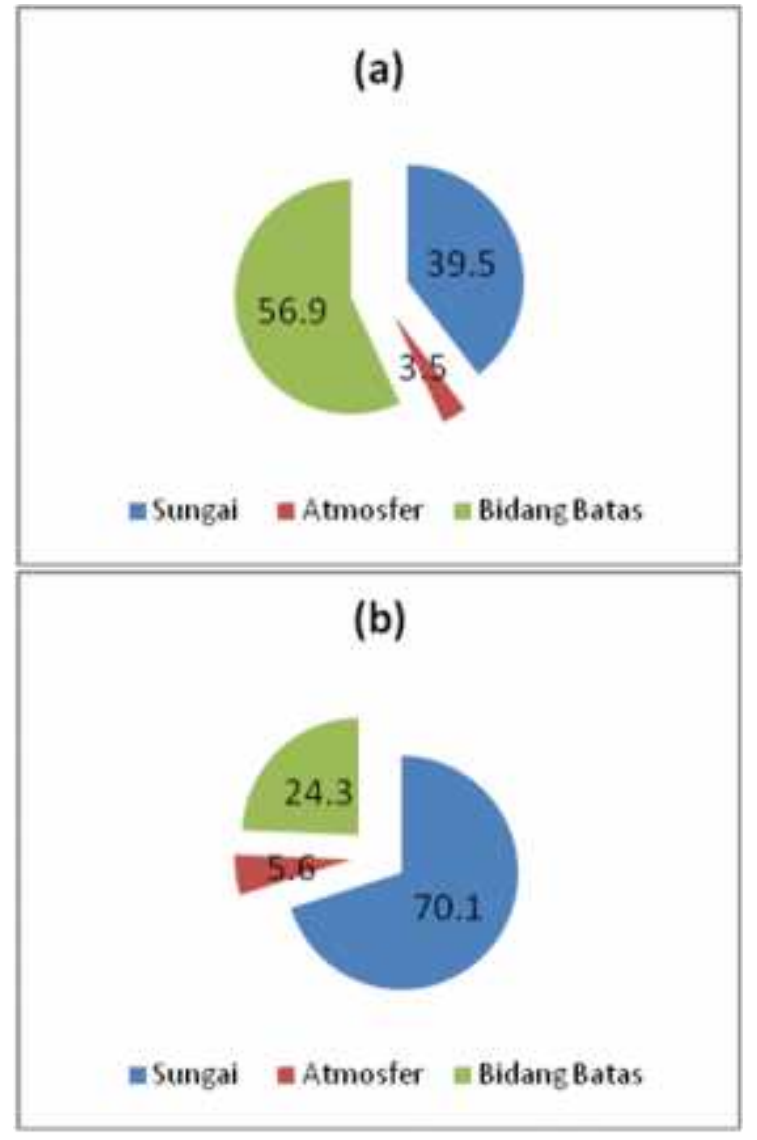

Gambar 5. Persentase load $\mathrm{NH}_{4}$ (a) dan $\mathrm{NO}_{3}$ (b) di Teluk Jakarta

\subsubsection{Load dari sungai}

Load sungai terkecil hingga terbesar berasal dari Sungai Marunda, Sungai Priok, Sungai Angke dan Sungai Citarum (Gambar 6). Tingkat load yang terjadi tersebut sesuai dengan besar debit sungai yang masuk dalam Teluk Jakarta. Sungai Citarum merupakan sungai yang memiliki wilayah yang luas dengan masukan air dari anak sungai yang banyak. Sungai Citarum memiliki panjang 268,80 $\mathrm{km}$, lebar $75 \mathrm{~m}$, memiliki 2.235 anak sungai, dan kedalaman muara berkisar antara 5-10 m (BPDAS Citarum-Ciliwung, 2010; Koropitan et al., 2009). Luasan Sungai Citarum yang besar (fungsi dari kedalaman dan lebar sungai), serta aliran sungai yang deras mengakibatkan debit air Sungai Citarum juga menjadi besar, sehingga load nutrien yang masuk dalam Teluk Jakarta juga besar. Menurut Hidayat (2013) debit sungai citarum mencapai mencapai puncaknya saat musim barat yaitu berkisar $578 \mathrm{~m}^{3} /$ detik dan berkurang saat musim kemarau.

Pola arus di Indonesia sangat dipengaruhi oleh musim. Pada bulan Desember bertiup angin muson barat, yang mengakibatkan arus bergerak dari barat ke timur (Wyrtki, 1961). Hal ini menyebabkan arus sisa permukaan dan dasar air (Gambar 2) di Teluk Jakarta bergerak menuju Laut Jawa (Koropitan et al., 2009) Letak Sungai Citarum yang berada pada ujung bagian timur Teluk Jakarta, mengakibatkan massa air Sungai Citarum cenderung langsung bergerak menuju Laut Jawa, sehingga Load dari 
Sungai Citarum tidak memberikan kontribusi pencemar yang besar di Teluk Jakarta saat musim barat.

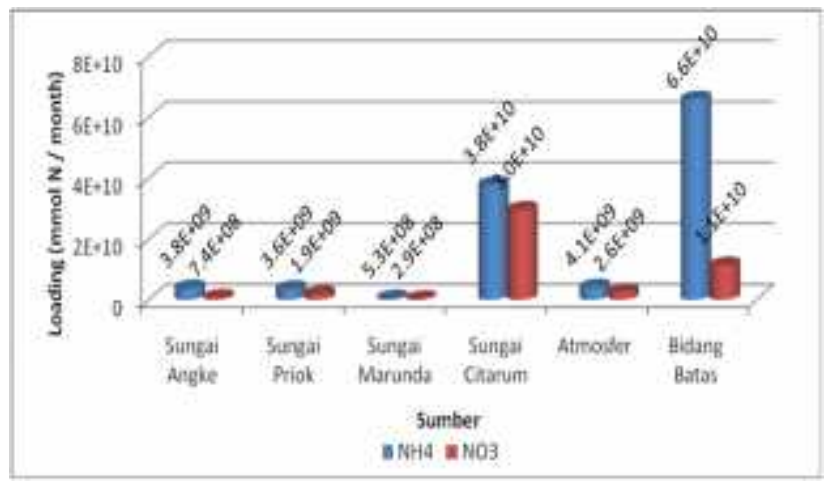

Gambar 6. Input load $\mathrm{NH}_{4}$ (biru) dan $\mathrm{NO}_{3}$ (merah) di Teluk Jakarta

Dari hasil perhitungan menunjukkan bahwa Load $\mathrm{NH}_{4}$ seluruh sungai lebih besar dibandingkan dengan load dari $\mathrm{NO}_{3}$. Hal ini disebabkan sumber $\mathrm{NH}_{4}$ yang lebih besar dibandingkan dengan sumber $\mathrm{NO}_{3}$. Chester (1990) mengemukakan sumber utama $\mathrm{NH}_{4}$ berasal dari buangan limbah organik yang terurai oleh bakteri, penggunaan pupuk pertanian dan sisa kotoran hewan ternak.

Load $\mathrm{NH}_{4}$ Sungai Citarum lebih tinggi dibandingkan load $\mathrm{NO}_{3}$ yang menunjukkan pula kondisi limbah Sungai Citarum. Sumber utama dari limbah $\mathrm{NH}_{4}$ adalah dari sektor pertanian, peternakan dan pabrik. Penggunaan pupuk di sawah yang berlebih merupakan faktor utama tingginya limbah $\mathrm{NH}_{4}$ di yang masuk kesungai. Untuk aktivitas peternakan sendiri, $\mathrm{NH}_{4}$ di hasilkan dari sisa kotoran kotoran berupa $\mathrm{NH}_{3}$ yang membentuk ikatan dengan $\mathrm{H}_{2} \mathrm{O}$. Menurut Wardhani (2010) di sungai Citarum terdapat 151 pabrik yang membuang secara langsung air sisa produksinya ke sungai ini dan beberapa industri ini menghasilkan amoniak $\left(\mathrm{NH}_{3}\right)$ dan $\mathrm{NH}_{4}$.

Sungai Marunda memiliki debit yang paling kecil dibandingkan Sungai Citarum, Angke dan Priok. Kedalaman Sungai Marunda pun berkisar antara 0-5 m (Koropitan et al., 2009). Debit Sungai Marunda yang kecil dan konsentrasi bahan pencemar yang relative rendah menyebabkan kontribusi load nutrien pada Teluk Jakarta juga kecil. Meski demikian, karena arus yang keluar dari Sungai Marunda terbawa oleh angin musim barat dan bergerak ke arah timur melalui tepi Teluk Jakarta, menyebabkan seluruh load nutrien yang terbawa oleh arus menuju ke bagian timur Teluk Jakarta.

\subsubsection{Load dari atmosfer}

Masukan $\mathrm{NH}_{4}$ dan $\mathrm{NO}_{3}$ dari atmosfer dihitung dari air hujan yang jatuh di permukaan Teluk Jakarta. Atmosfer memberikan kontribusi yang lebih besar dibandingkan dengan Sungai Angke, Priok, dan Marunda (Gambar 6). Kondisi ini disebabkan karena curah hujan di Teluk Jakarta pada Desember 2000 sangat tinggi yaitu $225 \mathrm{~mm}$, curah hujan ini jauh lebih besar dibandingkan pada saat Juli 2001 yang hanya mencapai $30.4 \mathrm{~mm}$ (Koropitan et al., 2009). Curah hujan yang jatuh di Indonesia (termasuk Teluk Jakarta) sangat tekait dengan pola angin muson yang selalu memiliki arah tiupan yang berubah-ubah sepanjang tahun tergantung dari posisi matahari (Wyrtki, 1961). Pada bulan Desember posisi matahari sedang berada di Belahan Bumi Selatan (BBS), hal ini menyebabkan tekanan udara di Belahan Bumi Utara (BBU) lebih tinggi dibandingkan dengan BBS. Angin pada bulan ini bertiup dari arah Benua Asia menuju Benua Australia, pada saat ini Indonesia mengalami musim penghujan, faktor ini yang menyebabkan tingginya load nutrien dari atmosfer.

Dari total load atmosfer menunjukkan bahwa load $\mathrm{NH}_{4}\left(4,10 \times 10^{9} \mathrm{mmol} \mathrm{N} /\right.$ bulan) lebih besar dibandingkan dengan load $\mathrm{NO}_{3}\left(2,59 \times 10^{9} \mathrm{mmol} \mathrm{N} /\right.$ bulan) (Gambar 4). Tingginya sumber pencemaran $\mathrm{NH}_{4}$ yang masuk ke atmosfer dibandingkan dengan $\mathrm{NO}_{3}$ diduga menjadi pemicu utama terjadinya fenomena ini. Bahera et al., (2013) menjelaskan sumber utama $\mathrm{NH}_{4}$ di atomsfer adalah $\mathrm{NH}_{3}$ yang berasal dari aktivitas pertanian (pengunaan pupuk) dan kotoran hewan ternak. Ditambahkan oleh Hill (2010) Emissi $\mathrm{NH}_{3}$ ke atmosfer tiga kali lebih besar dibandingkan dengan $\mathrm{NO}_{x} . \quad \mathrm{NH}_{3}$ di atmosfer akan melakukan reaksi dengan uap air dan kemudian membentuk $\mathrm{NH}_{4}$ yang kemudian akan turun kembali bersama dengan proses hujan. Sutton et al., (2009) menjelaskan faktor lain yang dapat menyebabkan konsentrasi $\mathrm{NH}_{4}$ tinggi dari atmosfer karena $\mathrm{NH}_{3}$ akan mengalami proses konversi $\mathrm{ke} \mathrm{NH}_{4}$ hanya dalam beberapa jam saja, sedangkan $\mathrm{NH}_{4}$ yang sudah berikatan dengan aerosol dapat bertahan dalam jangka waktu yang lebih lama di atmosfer. $\mathrm{NH}_{4}$ dalam jumlah yang berlebihan bersifat toksik bagi tumbuhan dan hewan (van Katwijk et al.,1997; Hecnar, 1995), misalkan pada Zostera marina akan mengalami nekrotik jika terpapar $\mathrm{NH}_{4}$ sebesar $125 \mu \mathrm{M}$ (van Katwijk et al.,1997) .

\subsubsection{Load dari bidang batas}

Bidang batas mempengaruhi konsentrasi nutrien di Teluk Jakarta sebagai input yang menambah load maupun output yang menjadi pengurang load. Pada musim barat, dimana angin menyebabkan arus bergerak dari barat ke timur, menyebabkan bagian barat Teluk Jakarta menjadi bidang batas input load, sedangkan bagian timur Teluk Jakarta menjadi output load. Hasil analisis load akibat bidang batas menunjukkan bahwa input load $\mathrm{NH}_{4}$ lebih tinggi dibandingkan $\mathrm{NO}_{3}$ (Gambar 6), begitu pula dengan outputnya $\left(6,9 \times 10^{10} \mathrm{mmol} \mathrm{N} /\right.$ bulan untuk $\mathrm{NH}_{4}$ dan $2,0 \mathrm{x}$ $10^{10} \mathrm{mmol} \mathrm{N} /$ bulan untuk $\mathrm{NO}_{3}$ ). Tingginya $\mathrm{NH}_{4}$ pada input bidang batas disebabkan karena adanya pengaruh masukan massa air dari arah barat menuju Teluk Jakarta. Prasono dan Kastoro (1979) mengemukakan bahwa pada musim barat, massa air di Teluk Jakarta sangat dipengaruhi oleh massa air berasal dari Selat Karimata, terutama dari Pulau Sumatera dan Kalimantan. Pasokan massa air dari bidang batas ini banyak mengandung $\mathrm{NH}_{4}$ dibandingkan $\mathrm{NO}_{3}$, hal ini diduga karena jumlah perkebunan dan pertanian di Pulau Sumatera dan Kalimantan yang tinggi dan limbahnya dibawa sampai ke laut jawa termasuk Teluk Jakarta. Ditambahkan oleh Howarth et al. (2002) bahwa pertanian memberikan kontribusi pencemaran yang tinggi terhadap $\mathrm{N}$ di daerah pantai, terutama dari aktifitas pemupukan. 
Bidang batas bagian timur sebagai output mengakibatkan load nutrien yang terdapat di Teluk Jakarta menjadi berkurang akibat pergerakan massa air. Total load dari sungai, atmosfer, dan bidang batas barat yang lebih didominasi oleh load $\mathrm{NH}_{4}$ mengakibatkan massa air di Teluk Jakarta mengandung $\mathrm{NH}_{4}$ lebih banyak. Hal ini mengakibatkan ketika arus bergerak keluar dari Teluk Jakarta menuju ke arah timur, massa air Teluk Jakarta tersebut juga mengandung $\mathrm{NH}_{4}$ lebih tinggi. Meski demikian, secara umum load akibat bidang batas sebelah barat (input) lebih rendah dibandingkan bidang batas timur (output). Artinya bila masukan load nutrien pada Teluk Jakarta hanya berasal dari bidang batas saja, maka pencemar nutrien tersebut masih dapat dibawa keluar dari dalam Teluk oleh pergerakan massa air pada musim barat.

\subsection{Kapasitas Asimilasi}

Kapasitas asimilasi merupakan kemampuan suatu lingkungan atau ekosistem untuk memulihkan diri ke kondisi semula apabila terdapat masukan pencemar yang dapat merusak lingkungan atau ekosistem tersebut. Pada perhitungan, diperoleh hasil kapasitas asimilasi $\mathrm{NH}_{4}$ di Teluk Jakarta sebanyak $2,57 \times 10^{10} \mathrm{mmol}$ N/bulan dan untuk $\mathrm{NO}_{3}$ sebanyak $2,41 \quad x \quad 10^{10}$ mmol N/bulan, sedangkan total akumulasi bahan pencemar yang masuk ke teluk Jakarta sangat besar yaitu $\mathrm{NH}_{4}$ sebesar 4,63 x $10^{10} \mathrm{mmol} \mathrm{N} /$ bulan dan $\mathrm{NO}_{3}$ sebesar $2,67 \times 10^{10} \mathrm{mmol}$ $\mathrm{N} /$ bulan. Dengan total load dan akumulasi yang terjadi, menandakan bahwa load $\mathrm{NH}_{4}$ dan $\mathrm{NO}_{3}{ }^{-}$yang masuk ke dalam Teluk Jakarta telah melebihi kapasitas asimilasi (Gambar 7) dan menyebabkan daya dukung Teluk Jakarta mengalami penurunan dan berimbas pada kelayakan dan fungsi utama Teluk Jakarta. Bila hal ini terjadi secara terus menerus, tanpa adanya penanganan yang serius dari semua pihak maka kemungkinan kapasitas asimilasi Teluk Jakarta akan semakin menurun sepanjang tahun yang kemudian akan meluas dan berdampak pada berbagai sektor seperti perikanan dan pariwisata.

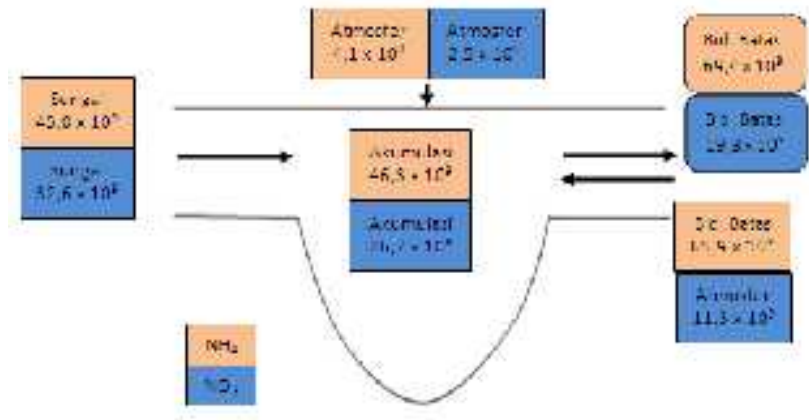

Gambar 7. Kesetimbangan nutrient di Teluk Jakarta

\subsection{Waktu Tinggal (Residence Time)}

Residence time merupakan waktu yang diperlukan suatu badan air untuk mengurangi konsentrasi polutan yang masuk dari inflow. Penghitungan residence time diperoleh, bahwa sistem badan air di Teluk Jakarta memerlukan 13,3 hari untuk dapat mengeluarkan load nutrien yang masuk ke dalam Teluk Jakarta, baik melalui pergerakan outflow, pengendapan, maupun pemanfaatan secara biologis. Waktu tinggal nutrien tersebut adalah 8,6 hari untuk $\mathrm{NH}_{4}$ dan 9,2 hari untuk $\mathrm{NO}_{3}$, sehingga menyebabkan waktu yang dimiliki oleh badan air Teluk Jakarta untuk mengeluarkan load nutrien lebih lama daripada peluruhan nutrien itu sendiri. Hal tersebut menyebabkan nutrien akan semakin sulit keluar dari wilayah Teluk Jakarta dan penumpukan load akan terjadi.

\section{Simpulan}

Dari penelitian ini dapat ditarik kesimpulan bahwa Teluk Jakarta memiliki total load bahan pencemar $\mathrm{NH}_{4}$ sebesar $115,8 \times 10^{9} \mathrm{mmol} \mathrm{N} /$ bulan dan $\mathrm{NO}_{3}$ sebesar 46,5 × $10^{9}$ mmol N/bulan. Penyumbang terbesar untuk pencemaran $\mathrm{NH}_{4}$ berasal dari bidang batas sebesar 56,9\% sedangkan untuk $\mathrm{NO}_{3}$ berasal dari sungai sebesar $70,1 \%$. Kapasitas asimilasi teluk Jakarta untuk $\mathrm{NH}_{4}$ sebesar 25,7 x $10^{9}$ mmol N/bulan dan $\mathrm{NO}_{3}$ sebesar $24,1 \times 10^{9} \mathrm{mmol} \mathrm{N} / \mathrm{bulan}$. Hal ini menunjukkan total load bahan pencemar yang memasuki Teluk Jakarta lebih besar dari kapasitas asimilasi teluk. Waktu tinggal air di dalam teluk Jakarta selama 13,3 hari lebih besar dibandingkan waktu tinggal $\mathrm{NH}_{4}$ dan $\mathrm{NO}_{3}$ yang hanya 8,6 dan 9,2 hari.

\section{Daftar Pustaka}

Ahmad, F. (2012). Kandungan senyawa Polisiklik Aromatik Hidrokarbon (PAH) di Teluk Jakarta. Ilmu Kelautan, 17(4), 199-208.

Aldrian, E, \& Susanto, R. D. (2003). Identification of three dominant rainfall regions within Indonesia and their relationship to sea surface temperature. International Journal of Climatology, 23(12), 14351452.

Alfiansah, Y. R., Adindasari, M., Argarini, M., Darmayati, Y., \& Ruyitno. (2014). Isolation and distribution of crude oil and polycyclic aromatic hydrocarbondegrading bacteria from polluted harbours in North Jakarta. Marine Resesearch Indonesia, 39(2), 79-85

Arifin, Z. (2004). Local millenium ecosystem assessment: condition and trend of the greater Jakarta Bay ecosystem. Jakarta: The Indonesian Ministry of Environmental.

As-syakur, A. R. (2015). Spatio-Temporal Variations of Rainfall and SST Anomaly over Indonesia during ENSO Modoki Event in 2010. Journal of Marine and Aquatic Sciences, 1(1), 23-29.

Behera, S. N., Sharma, M., Aneja, V. P., \& Balasubramanian, R. (2013). Ammonia in the atmosphere: a review on emission sources, atmospheric chemistry and deposition on terrestrial bodies. Environmental Science and Pollution Research, 20(11), 8092-8131.

BPDAS Citarum-Ciliwung. (2010). Rencana Pengelolaan DAS Terpadu Citarum Hulu. Bogor-Indonesia: Direktorat Jenderal Perhutanan Sosial dan Pengelolaan. Kementerian Kehutanan.

Chester, R. (1990). Marine Geochemistry. London: Unwin Hyman ltd 
Environmental Protection Autority (EPA). 2009. Load Calculation Protocol. for use by holders of NSW environment protection licences when calculating assessable pollutant loads. Sydney South: Departement of Environmental and Climate Change NSW.

Hecnar, S. J. (1995). Acute and chronic toxicity of ammonium nitrate fertilizer to amphibians from Southern Ontario. Environmental Toxicology and Chemistry, 14(12), 2131-2137.

Hidayat, Y., Martilaksono, K., Wahjunie, E. D., \& Panuju, D. R. (2013). Pencirian Debit Aliran Sungai Citarum Hulu. Jurnal Ilmu Pertanian Indonesia, 18(2), 109-114.

Hill, M. K. (2010). Understanding environmental pollution. $3^{\text {rd }}$ edition. United Kingdom: Cambridge University Press.

Howarth, R. W., Sharpley, A ., \& Walker, D. (2002). Souurces of Nutrien Pollution to Coastal Waters in the United State: Implication for Achieving Coastal Water Quality Goal. Estuaries, 25(4b), 656-676.

van Katwijk, M. M., Vergeer, L. H. T., Schmitz, G. H. W. \& Roelois, J. G. M. (1997). Ammonium toxicity in eelgrass Zostera marina. Marine Ecology Progress Series, 157, 159-173.

KepMenLH no 110. (2003). Pedoman Penetapan Daya Tampung Beban Pencemaran Air Pada Sumber Air.

Koropitan, A. F., Ikeda, M., Damar, A., \& Yamanaka, Y. (2009). Influences of physical processes on the ecosystem of Jakarta Bay: a coupled physicalecosystem model experiment. ICES Journal of Marine Science: Journal du Conseil, 66(2), 336-348..

Kusuma, A. H. (2015). Variabilitas Senyawa Logam Berat $(\mathrm{Pb}, \mathrm{Cd}, \mathrm{Cu}, \mathrm{Ni}$ dan $\mathrm{Zn})$ terlarut dan sedimen di perairan Teluk Jakarta. Thesis. Bogor-Indonesia: Institut Pertanian Bogor.
Libes, S. M. (1992). An Introduction to Marine Biogeochemistry. New York: John Wiley and Sons

Nugrahadi, M. S., Yanagi, T., Tejakusuma, I. G., Adi, S., \& Darmawan, R. A. (2010). Seasonal variations of nutrient budgetsin Jakarta Bay, Indonesia. Marine Research in Indonesia, 35(1), 9-20

Putri, L. S. E., Prasetyo, A. D., \& Arifin, Z. (2012). Green Mussel (Perna viridis L.) As Bioindicator Of Heavy Metals Pollution At Kamal Estuary, Jakarta Bay, Indonesia. Journal of Environmental Research and Development, 6(3), 389-396.

Prasono, D. P., \& Kastoro, W. (1979). Evaluasi hasil pemonitoran kondisi perairan Teluk Jakarta tahun 1975-1979. Jakarta-Indonesia: Lembaga Oseanologi Indonesia.

Rositasari, R. (2011). Karakteristik Komunitas Foraminifera di Perairan Teluk Jakarta. Jurnal Ilmu dan Teknologi Kelautan Tropis, 3(2), 100-111.

Sanusi, H. S. \& Putranto, S. (2009). Kimia laut dan pencemaran. Proses Fisika kimia dan interaksinya dengan lingkungan. Bogor-Indonesia: Institut Pertanian Bogor.

Sutton, M. A., Reis, S., \& Baker, S. M. H. (2009). Atmospheric ammonia. detecting emission change and enviromnetal impact. United Kingdom: Springer Science.

Wardhani, E. (2010). Inventarisasi Beban Pencemar BOD Air Sungai Citarum di Wilayah Kabupaten Bandung. In Prosiding Seminar. Tjipto Utomo. Jawa Barat: Institut Teknologi Nasional.

Wyrtki, K. (1961). Scientific results of marine investigations of the South China Sea and the Gulf Of Thailand. Naga Report Volume 2. California: University of California.

(C) 2016 by the authors; licensee Udayana University, Indonesia. This article is an open access article distributed under the terms and conditions of the Creative Commons Attribution license (http://creativecommons.org/licenses/by/3.0/). 